\title{
A SEQUENTIAL EXPLANATORY INVESTIGATION OF TPACK: INDONESIAN SCIENCE TEACHERS' SURVEY AND PERSPECTIVE
}

\author{
Muhaimin Muhaimin ${ }^{1}$ D, Akhmad Habibi ${ }^{1}{ }^{1 D}$, Amirul Mukminin $^{1}$ (D) Ferdiaz Saudagar ${ }^{1}$ (D), \\ Robin Pratama $^{1}$ (D) Sri Wahyuni ${ }^{2}$, Ali Sadikin ${ }^{1}$ (D) Boy Indrayana ${ }^{1}$ (D) \\ ${ }^{1}$ Universitas Jambi (Indonesia) \\ ${ }^{2}$ STKIP Muhammadiyah Pagaralam (Indonesia) \\ muhaimin_73@yahoo.de,akhmad.habibi@unja.ac.id,amirmuk_06@gmail.com,ferdiaz.saudagar@unja.ac.id, \\ robin.pratama@gmail.com,sriwabyunipga86@gmail.com,ali.sadikin@unja.ac.id,boy_indrayana@unja.ac.id
}

Received January 2019

Accepted March 2019

\begin{abstract}
This sequential explanatory design aims at exploring science teachers' perceptions of technology integration regarding technological pedagogical content knowledge (TPACK) which focused on quantitative findings (survey) supported by qualitative findings (interview). The study involved 356 respondents for the survey and eight participants for the interview. Descriptive statistics, t-test and ANOVA were used in the quantitative data analysis while for the qualitative data analysis, a thematic process was conducted. Findings show that the science teachers' perception of their technological-based knowledge is lower than non-technological knowledge namely pedagogical and content knowledge. Further, qualitative findings informed in-depth information about technology integration referred to TPACK namely problems in technology integration, advantages of technology integration, students centered learning, knowledge of new technology and its classroom integration, and peer collaboration. Policy recommendation was established for the betterment of ICT integration in instruction, especially for developing countries.
\end{abstract}

Keywords - TPACK, Science teachers, Survey, Interview.

\section{To cite this article:}

Muhaimin, M., Habibi, A., Mukminin, A., Saudagar, F., Pratama, R., Wahyuni, S. et al. (2019). A sequential explanatory investigation of tpack: Indonesian science teachers' survey and perspective. Journal of Technology and Science Education, 9(3), 269-281. https://doi.org/10.3926/jotse.662

\section{Introduction}

Nowadays, technology is developing with rapid innovation, having influenced almost aspects of lives including education. In instruction, a teacher plays very crucial roles in the success of technology integration in classrooms because the best practice of teaching should be determined based on their analysis within the context of pedagogy and content needs (Niederhauser \& Lindstrom, 2018). Therefore, it is important to help teachers, pre-service and in-service, acquire and develop technological competence and intention to integrate technology into teaching (Barreto \& Orey, 2013). Many studies informed positive impacts of teachers' use of technology to have better students' learning (e.g., Awang, Aji, Yaakob, Osman, Mukminin, \& Habibi, 2018; Habibi et al., 2018). Specifically, researchers have informed their 
studies on the process of implementation, benefits, and problems in technology integration among science teachers (Incikabi, 2019; Thibaut, Knipprath, Dehaene, \& Depaepe, 2018).

Knowledge in relation to the effective implementation of technology in education is also important for the $21^{\text {st }}$-century teachers (ISTE, 2018). In the beginning, teachers taught their students focusing primarily on technology skills regardless of the pedagogical or content aspects (Graham, Culatta, Pratt \& West, 2004). Today's teachers including science teachers recognized that technological skills alone did not contribute well for students' learning promotion without teachers understanding how to use technology in effective ways related to pedagogical and subject content aspects. Therefore, the focus of educational technology studies has shifted from teaching merely technology skills to effectively integrating technology into teaching (Mishra \& Koehler, 2006).

In 2006, Mishra and Koehler found technological pedagogical and content knowledge (TPACK) which many researchers recognized this framework brings the influence of content domain in technology use in pedagogy. The new framework was established upon Lee Shulman's widely cited Pedagogical Content Knowledge (PCK) framework (Shulman, 1987). There have been many studies involved TPACK framework in technology integration in education in developed countries (e.g. Bostancioğlu \& Handley, 2018; Graziano, Herring, Carpenter, Smaldino, \& Finsness, 2017; Martin, 2018), including in science education (e.g. Barak, 2017; Constantine, Rozowa, Szostkowski, Ellis, \& Roehrig, 2017; Enderson \& Watson, 2019; Jang \& Tsai, 2013; Joo, Park, \& Lim, 2018; Lin, Tsai, Chai \& Lee 2013). However, very few studies have been conducted measuring TPACK teachers' level in Indonesia as one of the developing countries. Therefore, this mix method study was conducted to fill the gap. To achieve the research purposes, two guiding questions were established:

1. What is the Indonesian science teachers' level of TPACK?

2. Is there any significant difference of TPACK level between the science teachers in term of; gender, age, and teaching experience?

3. How do they perceive technology integration related to TPACK?

\section{Literature Review}

Todays' achieved science teachers are likely the teachers who successfully establish appropriate strategies of science knowledge to achieve successful teaching with technologies (Constantine et al., 2017). To measure the knowledge of technology integration into teaching, one well-known framework is TPACK developed by Mishra and Koehler (2006). They have highlighted the needs of modern teachers to bring pedagogical knowledge, technological knowledge, and content knowledge. In addition, they combined the complicated relationship among the domains.

\subsection{The Origin of TPACK}

The ideas in order to investigate factors affecting the integration of ICTs during teaching is not something new; however, it should always be updated with the influence of the development of education from time to time (Lawrence \& Tar, 2018). As discussed by Adnan and Tondeur (2018), today's teacher training programs still look for proper courses, trainings, and practices to improve teachers' competence in integrating ICTs into teaching. Studies have informed that some characteristics of teachers may affect the ICTs integration such as beliefs (Gne \& Bahivan, 2018) self-efficacy (Krause, 2017; Yerdelen-Damar, Boz \& Aydın-Günbatar, 2017), attitudes (Suana, 2018), and acceptance (Kale, 2018). Those characteristics are related to teachers' comprehension of some technological devices regarding subject matter, students' needs and instructional condition (Adnan \& Tondeur, 2018). Beyond that, many teacher training programs have changed their paradigm to exploring competencies of ICTs with regard to knowledge perspective which firstly based on Shulman's (1987) pedagogical content knowledge (PCK).

TPACK, formerly TPCK (Mishra \& Koehler, 2006), has been stimulating teacher training programs to form teacher's knowledge, pre-service and in-service, with a concise framework that involves integrates technology, pedagogy, and content in a direct way. This framework has been widely adopted and adapted by the educational application of ICT researchers from time to time (Baran, Canbazoglu-Bilici, 
Albayrak-Sari \& Tondeur, 2017; Bostancioğlu \& Handley, 2018; Graziano et al., 2017; Martin, 2018). The well-known Venn-circled diagram picturing three basic domains of TPACK; technological knowledge (TK), pedagogical knowledge (PK), and content knowledge (CK) is widely used in ICTs integration research. The intertwined domains (four domains) of the knowledge model are understood to be distinct domains essential of the basic knowledge domains; technological content knowledge (TCK), technological pedagogical knowledge (TPK), and pedagogical content knowledge (PCK), as well as technological pedagogical and content knowledge (TPACK). To more understand the seven factors, Mishra and Koehler (2006) have defined TPACK in simple explanation (see Table 1).

\begin{tabular}{|c|c|}
\hline Domain & Definition \\
\hline TK & Knowledge of existing technologies e.g. using computers, smartphone and the Internet \\
\hline PK & $\begin{array}{l}\text { Knowledge of teaching e.g. teaching principles, students' psychology of students, teaching } \\
\text { strategies, and management of class }\end{array}$ \\
\hline CK & Subject matter knowledge, for instance, scientific, social, and linguistic knowledge \\
\hline TCK & $\begin{array}{l}\text { Knowledge of integrating existing technologies for certain subject matter knowledge which } \\
\text { excludes pedagogical aims; the knowledge of applying simulation to inform tree population } \\
\text { development }\end{array}$ \\
\hline TPK & $\begin{array}{l}\text { Knowledge of integrating existing technologies in pedagogy such as engaging a web } 2.0 \text { in teaching } \\
\text { chemistry }\end{array}$ \\
\hline PCK & $\begin{array}{l}\text { knowledge of changing specific content into an understandable and accessible form for learners } \\
\text { via an approach of pedagogy e.g. the knowledge of how to deliver some scientific theories }\end{array}$ \\
\hline TPACK & $\begin{array}{l}\text { Knowledge of implementing technologies to improve students' understanding and learning in } \\
\text { certain subject matter knowledge e.g. using Google Earth in teaching mount eruption }\end{array}$ \\
\hline
\end{tabular}

Table 1. Definition of domains of TPACK

In recent previous studies, researchers have extensively used the framework in variation of population of research, such as pre-service teachers (e.g. Scherer, Tondeur, Siddiq \& Baran, 2018; Tondeur, Scherer, Siddiq \& Baran, 2017; Yurdakul, 2018), in-service teachers (Chen \& Jang, 2018; Hsu,Tsai, Chang, \& Liang, 2017), online distance teachers (Joo et al., 2018; Dalal, Archambault \& Shelton, 2017), and teachers in professional development courses (Harris \& Hofer, 2017; Koh, Chai \& Lim, 2017). The importance of TPACK studies will be developed from time to time and differences between countries due to technology development and educational policy. Emphasizing teachers' TPACK development is also crucial for different research populations including for science teacher education.

\subsection{Science Teachers' TPACK}

In-service teachers training programs have broadly achieved the general agreement of technologies that deliver a huge impact on instruction (Dalal et al., 2017). It has been recommended that ICT for instructional strategies to improve for example science learning; provoking cognitive factors (Tchoshanov, Cruz, Huereca, Shakirova, Shakirova \& Ibragimova, 2017) and providing adaptation in learning with scaffolding (Niess, 2018). In more general terms, technologies have been continuously informed and discussed for its contribution to learning strategies namely, cooperative learning, problem-based learning, contextual learning, and situated learning as well as collaborative learning (Ifinedo, Kankaanranta, Neittaanmäki \& Hämäläinen, 2017).

However, some critics have addressed to the inclusion of technological applications in science as excessively technocentric (Chai, Koh, \& Tsai 2010). The technocentric approach also failed to address the gaps between technology integration theories and practice in educational settings where science teachers could experience many barriers; technology facilities, teachers' technology attitudes and knowledge, technology funding, traditional style of teaching, professional development, district and school culture (Alkhawaldeh \& Menchaca, 2014; Ertmer, Ottenbreit-Leftwich, Sadik, Sendurur, \& Sendurur, 2012). In authentic classroom circumstances, teachers should do essential efforts to achieve technology integration for the specific topic for specific students. As such, science teachers need to consider students' need and ability to learn using technology. One of the comprehensive frameworks to minimize this is the TPACK 
Studies have also been addressed within the context of TPACK in science studies (Barak, 2017; Constantine et al., 2017; Enderson \& Watson, 2019; Joo et al., 2018). Teachers' attitudes for the TPACK are positively associated with instructional practices. A different aspect of school context affects practices (Constantine et al., 2017). In addition, Enderson and Watson (2019) informed a case approach applied for modeling and simulation applications in a science, technology, engineering, and mathematics (STEM) teacher preparation program to help the establishment of the TPACK. In science, technology has been emphasized to enhance the learning of the concepts (Joo et al., 2018) and thought as a strong toll supporting learners' activities. In such condition, science teachers must be trained with related knowledge to integrate ICTs in instructional activities.

Many applicable models of TPACK have been explored by researchers in order to employ academic proof to agree on the framework. Mishra and Koehler (2006) developed an instrument of a survey to assess the effect of a course in accordance with their TPACK which related to the seven domains. However, it was in nature course so that it did not represent the TPACK model for teachers whose major are not natural science. On the other hand, Lee and Tsai (2010) surveyed teachers' TPACK specifically for content Knowledge-Web technology. Lin et al. (2013) and Jang and Tsai (2013) develop survey instruments to examine science teachers' TPACK that were used in this current study.

\section{Method}

\subsection{Design of the Study}

Mix method study, sequential explanatory design, is conducted to explore a phenomenon of the study within involving some data sources as well as establishing reliability and validity of the findings (Creswell, 2014). Sequential explanatory design relies on the quantitative data supported by qualitative data to achieve the purposes of the study (Creswell, 2014) Through this method, we did an investigation of TPACK level of Indonesian science teachers, the difference of TPACK level between the science teachers in term of; gender, age, and teaching experience, and the science teachers' perception of technology integration related to TPACK. The study was done for eight months from November 2017 to June 2018 in one Indonesian province. This study is part of a bigger study examining Indonesian K-12 school teachers' technology integration funded by the Indonesian ministry of higher education, research and technology.

We used two kinds of data sources, survey and interview, in order to answer the research questions. In mix method study, multiple data methods e.g. survey, observation, interviews, group discussion, and document analysis are significant (Stake, 1995). The data collection method should be related to research approaches. The two data collection methods are important to provide full and detail information in this study. This study was begun with a quantitative process followed by qualitative data collection and analysis.

\subsection{Quantitative}

The population of this study is all Indonesian high school science teachers. However, the sample was 356 science teachers who teach in one Indonesian province (see Table 2). We distributed survey printed survey instruments to 500 science teachers where 402 instruments were returned and 46 instruments were not able to calculate; some statements were not answered by the respondents.

In considering and identifying a suitable survey instrument to investigate Indonesian science teachers' level of TPACK, we adapted a survey from a previous study (Lin et al., 2013; Jang \& Tsai, 2013). The instrument which standardized validity coefficient was from .71 to .93 applied SEM in constructing the model. There were 27 items included in the 7 domains of TPACK; four items of technological knowledge (TK), 6 items of pedagogical knowledge (PK), 3 items of content knowledge (CK), 3 items of technological content knowledge (TCK), 5 items of technological pedagogical knowledge (TPK), 2 items of pedagogical content knowledge (PCK), as well as 4 items of technology, pedagogy, and content (TPC).

The instrument was discussed by a panel of educational technology experts and English- Indonesian translation experts for content validity before being distributed. The discussion with the experts of educational technology aimed at agreeing the technological application in the original instrument (Lin et al., 2013; Jang \& Tsai, 2013) with the condition of Indonesian schools. In addition, the translation experts 
were involved since the survey items were translated from English to Bahasa Indonesia. Based on the content validity, some wordings were changed such as "I have the technical skills to use computers effectively" to be "I have the technical skills to use the internet and computers effectively". One item in TPK was eliminated due to the context matter. Therefore, the final survey of this study consists of 26 items for TPACK domain questions with an average internal consistency of .86 acceptable for the TPACK. Four items for demographic information (gender, age, and teaching experience)

We distributed the survey questionnaires helped by two high school teachers and one research assistant. After the data collection, we computerized the data and saved them into Microsoft Excel. We then calculated the data and measured their frequency, percentage, mean, and standard deviation (descriptive statistics) to investigate the teachers' TPACK level. We used t-test and ANOVA to evaluate the differences among moderating variables. We used t-test and ANOVA to evaluate the differences among moderating variables.

\begin{tabular}{|c|c|c|}
\hline \multirow[b]{2}{*}{ Variables } & \multirow[b]{2}{*}{ Sub-variable } & The respondents (n. 356) \\
\hline & & F (\%) \\
\hline \multirow{2}{*}{ Gender } & Male & $123(34.55)$ \\
\hline & Female & $233(65.45)$ \\
\hline \multirow{3}{*}{ Age (years) } & $25-35$ & $97(27.25)$ \\
\hline & $36-45$ & $147(41.29)$ \\
\hline & $46-55$ & $112(31.46)$ \\
\hline \multirow{3}{*}{ Teaching experience (years) } & $1-10$ & $105(29.49)$ \\
\hline & $11-20$ & $121(33.99)$ \\
\hline & $21-30$ & $130(35.52)$ \\
\hline
\end{tabular}

Table 2. Survey respondent information

\subsection{Qualitative}

To more understand science teachers understanding of technology integration in their school, we interviewed eight participants who filled in "yes" in agreement statement in the survey. Semi-structure interview questions were adapted from the survey items. These questions were listed to understand how interventions push and how they are allowing interviewers to have talks on the issues that may not be brought in the other study method of data collection (Creswell, 2014).

In the agreement column of the questionnaire, twenty-five science teachers filled in "yes" but we contacted only eight teachers whose age range from 25-50 years old (see Table 3). The interviews were conducted to obtain in-depth information in relation to the technology integration in for their teaching subject, science. The interviews were carried out in Bahasa Indonesia lasting from 40 to 45 minutes. We masked the participants' identities using pseudonyms for ethical consideration of in order to keep safe human right protection. Science teachers' decision to be in the study for the interview sessions was voluntary as we provided them informed-consent forms.

For the data analysis, we implemented what (Miles \& Huberman, 1994) called "within case analysis." We interviewed the eight participants one by one by audio-taping. After that, we did data transcription suing Google voice doc. We analyzed and categorized the transcriptions into thematic items. This process was repeated until the last participant, the eight participants. We marked relevant chunks of statements, put relevant chunks of statements into permanent categories and translated the categories from Bahasa Indonesia into English (Creswell, 2014). For the trustworthiness (Miles \& Huberman, 1994) of the study, we addressed verbatim statements of the transcription followed by member checking procedures (Creswell, 2014; Habibi et al., 2018). We did checking procedures with both all participants of the interview and all researchers' members. We gave the interview data to the participant to obtain their feedback and agreement. This step was conducted in order to decrease the bias of the research. The participants agreed the data of the study to be presented. 


\begin{tabular}{|c|r|r|r|}
\hline $\begin{array}{c}\text { Names } \\
\text { (pseudonyms) }\end{array}$ & Gender & Age (years) & $\begin{array}{c}\text { Science teaching } \\
\text { experience (years) }\end{array}$ \\
\hline Ryan & $\mathrm{M}$ & 28 & 3 \\
\hline Siti & $\mathrm{F}$ & 44 & 19 \\
\hline Kendal & $\mathrm{F}$ & 53 & 32 \\
\hline Thomas & $\mathrm{M}$ & 45 & 21 \\
\hline Febby & $\mathrm{F}$ & 34 & 10 \\
\hline Katty & $\mathrm{F}$ & 51 & 23 \\
\hline Budi & $\mathrm{M}$ & 34 & 11 \\
\hline Cassie & $\mathrm{F}$ & 46 & 23 \\
\hline
\end{tabular}

Table 3. Participants in the interview and the location

\section{Findings}

\subsection{Indonesian Science Teachers' Level of TPACK?}

Firstly, the seven domains of TPACK were separately calculated for the mean, standard deviation, and Cronbach alpha (see Table 4). The highest score of the domain of the survey was CK (mean $=3.92$, $\mathrm{SD}=0.51)$ which states "I have sufficient knowledge of science" gained the highest (mean $=4.00)$. Following CK, it was PK and PCK gaining the second lowest mean scores of TPACK perceived by Indonesian science teachers (mean $=3.78, \mathrm{SD}=.53$; mean $=3.76, \mathrm{SD}=.55$ ). All technological-based knowledge domains lower scores of mean; TK (mean $=3.12, \mathrm{SD}=.77)$, TPK (mean $=3.02, \mathrm{SD}=1.08$ ), TCK (mean $=3.00, \mathrm{SD}=1.12$ ), and TPC (mean= 2.13, $\mathrm{SD}=1.15)$. The Cronbach Alpha ranges from .83 to .89 which is considered "good".

\begin{tabular}{|c|c|c|c|}
\hline Domains of TPACK & Mean & SD & $\alpha$ \\
\hline Technological Knowledge & 3.12 & .77 & .84 \\
\hline I have the technical skills to use the internet and computers effectively & 3.11 & .76 & \\
\hline I learn technology easily & 3.12 & .77 & \\
\hline I know how to solve my own technical problems when using technology & 3.14 & .78 & \\
\hline I keep up with popular new technologies & 3.10 & .79 & \\
\hline Pedagogical Knowledge & 3.78 & .53 & .83 \\
\hline I am able to stretch my students' thinking by creating challenging tasks for them & 3.86 & .45 & \\
\hline I am able to guide my students to adopt appropriate learning strategies & 3.87 & .48 & \\
\hline I am able to help my students to monitor their own learning & 3.80 & .52 & \\
\hline I am able to help my students to reflect on their learning strategies & 3.75 & .53 & \\
\hline I am able to plan group activities for my students & 3.73 & .54 & \\
\hline I am able to guide my students to discuss effectively during group work & 3.65 & .54 & \\
\hline Content Knowledge & 3.92 & 0.51 & .85 \\
\hline I have sufficient knowledge of science & 4.00 & .49 & \\
\hline I can think about the content of science like a subject matter expert & 3.90 & .53 & \\
\hline I am able to develop a deeper understanding of the content of science & 3.86 & .50 & \\
\hline Technological Pedagogical Knowledge & 3.02 & .83 & .87 \\
\hline I am able to use technology to introduce my students to real-world scenarios & 3.08 & .81 & \\
\hline $\begin{array}{l}\text { I am able to facilitate my students to use technology to find more information on } \\
\text { their own }\end{array}$ & 3.00 & .85 & \\
\hline $\begin{array}{l}\text { I am able to facilitate my students to use technology to plan and monitor their } \\
\text { own learning }\end{array}$ & 3.03 & .83 & \\
\hline I am able to facilitate my students to collaborate with each other using technology & 2.98 & .78 & \\
\hline Pedagogical Content Knowledge & 3.76 & 0.55 & - \\
\hline $\begin{array}{l}\text { Without using technology, I can address the common misconceptions my students } \\
\text { have about science }\end{array}$ & 3.75 & .57 & \\
\hline
\end{tabular}




\begin{tabular}{|c|c|c|c|}
\hline Domains of TPACK & Mean & SD & $\alpha$ \\
\hline $\begin{array}{l}\text { Without using technology, I can help my students to understand the content } \\
\text { knowledge of science in various ways }\end{array}$ & 3.77 & .55 & \\
\hline Technological Content Knowledge & 3.00 & .81 & .89 \\
\hline $\begin{array}{l}\text { I can use the software that is created specifically for science (e.g., data loggers for } \\
\text { science) }\end{array}$ & 3.09 & .82 & \\
\hline $\begin{array}{l}\text { I know about the technologies that I have to use for research of the content of } \\
\text { science }\end{array}$ & 3.09 & .81 & \\
\hline $\begin{array}{l}\text { I can use appropriate technologies (e.g., multimedia resources, simulation) to } \\
\text { represent the content of science }\end{array}$ & 2.95 & .80 & \\
\hline Technological Pedagogical and Content & 2.98 & .83 & .86 \\
\hline $\begin{array}{l}\text { I can teach lessons that appropriately combine science, technologies, and teaching } \\
\text { approaches }\end{array}$ & 3.07 & .82 & \\
\hline $\begin{array}{l}\text { I can select technologies to use in my classroom that enhance what I teach, how I } \\
\text { teach, and what students learn }\end{array}$ & 3.04 & .84 & \\
\hline $\begin{array}{l}\text { I can use strategies that combine science, technologies, and teaching approaches } \\
\text { that I learned about in my coursework in my classroom }\end{array}$ & 2.90 & .83 & \\
\hline $\begin{array}{l}\text { I can provide leadership in helping others to coordinate the use of science, } \\
\text { technologies, and teaching approaches in my school and/or district }\end{array}$ & 2.90 & .83 & \\
\hline
\end{tabular}

Table 4. Level of The Technological Pedagogical Content Knowledge of Indonesian science teachers (n356)

\subsection{The Difference of TPACK Level between the Science Teachers in Term of; Gender, Age and Teaching Experience?}

The t-test was conducted to gain differences in terms of respondents' gender (see Table 5). Even though, it was reported that there were no significant differences of scale scores of CK and TCK from both female and male respondents, most of the domains have been reported to have a significant difference. There were significant differences in scores for males (mean $=3.24, \mathrm{SD}=.81$ ) having higher scores of $\mathrm{TK}$ than that of females $(\mathrm{M}=3.00, \mathrm{SD}=.48)$ with $\mathrm{p}=.013$. Females (mean $=2.90, \mathrm{SD}=.79)$ informed lower scores than males (mean $=3.14, \mathrm{SD}=.79$ ) in TPK, $\mathrm{p}=.004$ along with TPC, females (mean=2.86, $\mathrm{SD}=.87$ ) than males (mean=3.10, $\mathrm{SD}=.80$ ), $\mathrm{p}=.004$. However, females (mean=3.87, $\mathrm{SD}=.54$ ) reported significantly higher scores than males (mean $=3.69, \mathrm{SD}=.46), \mathrm{p}=.024$ in PK as well as in PCK, females (mean $=3.82, \mathrm{SD}=.68$ ) than males (mean=3.65, $\mathrm{SD}=.5), \mathrm{p}=.049$.

A series of one-way ANOVA tests were done in order to compare scores in the TPACK domains in terms of age and teaching experience (see Table 6). One-way analysis of variance indicated significant differences in TK and TPK based on the age of respondents. Participants were divided into three groups according to their age $(25-35 ; 36-45$ and $46-55)$. There was a statistically significant difference at the $\mathrm{p}<.005$ level in TK scores for the three groups of age groups, $\mathrm{p}=.003$. In addition, there was a statistically significant difference at the $\mathrm{p}<.05$ level in TPK scores, $\mathrm{p}=.026$. There were no other significant differences in TPACK domain scores in terms of respondents' age and teaching experience. 


\begin{tabular}{|c|c|c|c|c|}
\hline Domain & Gender & Mean & SD & Sig \\
\hline \multirow{2}{*}{ TK } & Male & 3.24 & .81 & \multirow{2}{*}{$.014^{* *}$} \\
\hline & Female & 3.00 & .48 & \\
\hline \multirow{2}{*}{ PK } & Male & 3.69 & .46 & \multirow{2}{*}{$.024^{*}$} \\
\hline & Female & 3.87 & .54 & \\
\hline \multirow{2}{*}{ CK } & Male & 3.91 & .49 & \multirow{2}{*}{.604} \\
\hline & Female & 3.93 & .56 & \\
\hline \multirow{2}{*}{ TPK } & Male & 3.14 & .79 & \multirow{2}{*}{$.004^{* *}$} \\
\hline & Female & 2.90 & .83 & \\
\hline \multirow{2}{*}{ PCK } & Male & 3.65 & .55 & \multirow{2}{*}{$.049 *$} \\
\hline & Female & 3.82 & .68 & \\
\hline \multirow{2}{*}{ TCK } & Male & 3.11 & .76 & \multirow{2}{*}{.232} \\
\hline & Female & 2.89 & .89 & \\
\hline \multirow{2}{*}{ TPC } & Male & 3.10 & .80 & \multirow{2}{*}{$.004 * *$} \\
\hline & Female & 2.86 & .87 & \\
\hline
\end{tabular}

Table 5. The result of t-test of TPACK domains difference in term of gender

\begin{tabular}{|c|c|c|c|c|c|c|c|}
\hline \multirow[b]{2}{*}{ Age } & \multicolumn{7}{|c|}{ Demographic Information } \\
\hline & TK & PK & CK & TPK & PCK & TCK & TPC \\
\hline $25-35$ & 3.35 & 3.67 & 3.81 & 3.15 & 3.57 & 3.39 & 3.35 \\
\hline $36-45$ & 3.22 & 3.76 & 4.02 & 3.1 & 3.75 & 3.01 & 3.01 \\
\hline $46-55$ & 2.80 & 3.91 & 4.00 & 2.8 & 3.97 & 2.6 & 2.59 \\
\hline Sig. & $.004 * *$ & .711 & .876 & $.026 *$ & .825 & .121 & .069 \\
\hline \multicolumn{8}{|c|}{$\begin{array}{l}\text { Teaching } \\
\text { experience }\end{array}$} \\
\hline $1-10$ & 3.36 & 3.70 & 3.85 & 3.17 & 3.55 & 3.36 & 3.35 \\
\hline $11-20$ & 3.20 & 3.73 & 4.00 & 3.09 & 3.78 & 3.00 & 3.08 \\
\hline $21-30$ & 2.81 & 3.92 & 4.1 & 2.79 & 3.96 & 2.65 & 2.58 \\
\hline Sig. & .082 & .772 & .672 & .087 & .816 & .113 & .065 \\
\hline
\end{tabular}

Table 6. Result of ANOVA of TPACK domains difference in term of age and experience

\subsection{Perceived Technology Integration Related to TPACK}

To discuss the research question number three, science teachers' perception on technology integration in relation to TPACK, we interviewed the eight participants; the interview guiding questions were constructed based on the result of the survey analysis. The findings are thematic and explained in this section (see Table 7). the themes of this study consist of five items; problems in technology integration, advantages of technology integration, students; cantered learning, knowledge of new technology and its classroom integration, and peer collaboration.

Problems in technology integration are represented by nineteen statements which the elaboration can be related to TK, TPK, TCK, and TPACK. The problems varied from internal and external problems faced by the science teachers. Most teacher, especially senior ones, revealed that their skills of technology and technology integration in teaching were the most challenge that they have to deal with. Other teachers were complaining about the lack of infrastructure supporting technology integration, teachers' developments relate to technology integration, and lack of human resource or technology supporting technicians, as well as the limited support provided by school administrators. 


\begin{tabular}{|l|c|l|l|}
\hline \multicolumn{1}{|c|}{ Theme } & Statement Freq. & \multicolumn{1}{c|}{ Representative statement } & \multicolumn{1}{c|}{$\begin{array}{c}\text { Description } \\
\text { (related TPACK domain) }\end{array}$} \\
\hline $\begin{array}{l}\text { Problems in } \\
\text { technology } \\
\text { integration }\end{array}$ & 19 & $\begin{array}{l}\text { "As a senior teacher, I do not have } \\
\text { good skills of either ICT or its } \\
\text { integration in classrooms. That is the } \\
\text { major problems I have in the ICT } \\
\text { application" (Siti) }\end{array}$ & $\begin{array}{l}\text { The elaboration of problems faced in } \\
\text { technology integration (TK, TPK, } \\
\text { TCK, TPACK) }\end{array}$ \\
\hline $\begin{array}{l}\text { Advantages of } \\
\text { technology } \\
\text { integration }\end{array}$ & \multirow{2}{*}{$\begin{array}{l}\text { "In science, if you are good in } \\
\text { technology like simulation, video } \\
\text { applications, and others, it will be so } \\
\text { much supporting the instruction" } \\
\text { (Febby) }\end{array}$} & $\begin{array}{l}\text { The information on the advantages of } \\
\text { lCT integration in the teaching and } \\
\text { learning processes (TK, TPK, TCK, } \\
\text { TPACK) }\end{array}$ \\
\hline $\begin{array}{l}\text { Students } \\
\text { centered } \\
\text { learning }\end{array}$ & $\begin{array}{l}\text { "Science students welcome the use of } \\
\text { technology; they love searching } \\
\text { information on the Internet; it is } \\
\text { more complete information the } \\
\text { Internet provides" (Budi) }\end{array}$ & $\begin{array}{l}\text { The elaboration of students centered } \\
\text { learning through the integration of } \\
\text { technology (PK, CK, TPK, TPACK) }\end{array}$ \\
\hline $\begin{array}{l}\text { Knowledge of } \\
\text { new technology } \\
\text { and its } \\
\text { classroom } \\
\text { integration }\end{array}$ & 11 & $\begin{array}{l}\text { "I watched a good video in a Youtube } \\
\text { channel about science and found a } \\
\text { good application and simulation to be } \\
\text { applied in my classroom. I am happy } \\
\text { to share it with my students" (Cassie) }\end{array}$ & $\begin{array}{l}\text { The information of new technology } \\
\text { discovery that might be beneficial to } \\
\text { be implemented in teaching and } \\
\text { learning processes (TK, TPK, TCK, } \\
\text { TPACK). }\end{array}$ \\
\hline $\begin{array}{l}\text { "I discussed some technology } \\
\text { applications in my informal meeting } \\
\text { and it helps me integrate technology } \\
\text { in my instruction" (Thomas) }\end{array}$ & $\begin{array}{l}\text { The reflection of how the participants } \\
\text { collaborate by helping or informing } \\
\text { each other about the use technology } \\
\text { in the classroom (TK) }\end{array}$ \\
\hline
\end{tabular}

Table 7. Qualitative thematic evidence of TPACK

On the other hand, the advantages of technology in teaching and learning processes were also discussed. some advantages like facilitating interesting learning situation in the classroom, engaging critical learning, and improving peer collaboration among. One of the participants revealed that by using technology in the science classroom, the explanation of teaching material would be simpler and clearer. The information about the advantages of ICT integration in the teaching and learning processes is in close relation to domains of TK, TPK, TCK, TPACK. Further, on many occasions in the interview sessions, the interviewees underlined the learning style students possessed, should the technology integration be implemented in their teaching and learning processes. One of many quotes revealed,

Using technology namely the Internet makes students become more active and independent. They are more independent and sometimes more knowledgeable than we are (Kendal)

The science teacher in the interview also informed about knowledge of new technology and its application in the classroom. They gain new knowledge from what they learn and understand if the technology is used in their teaching and learning activity. One of the participants, Thomas, stated that he once knew about Edmodo and applied in his classes. He still uses the application until today. The teacher' information about the new technology discovery and its integration could be important in the instruction and related to TK, TPK, TCK, TPACK. Lastly, thirteen statements from the interviewees mentioned about peer collaboration in their technology integration promotion. They informed that peer collaboration helped them improve their skills and knowledge as well as self-efficacy in technology integration. The peer collaboration emerging from the qualitative data finding might be in relation to technological knowledge (TK).

\section{Discussion}

Results informing Indonesian science teachers' all seven TPACK domains, with CK informed as of the highest score obtained by the teachers followed by PK and PCK. Qualitatively, most Indonesian science teachers' technology said in the interview that they had been exposed to use technology in their teaching and learning processes for the only last five years. As a result, it might lower the level of domains' TK, 
TCK, and TPK. The findings contrast to previous findings (Joo et al., 2018) which informed the scores of TK, TCK, TPK, and TPACK were either similar or higher than the score of PK and CK as well as PCK. In general, there is no significant difference in terms of teaching experience and age of TPACK domains informed in this study. However, significant differences exist in term of gender where male respondents for TK, PK, TPK, and TPACK. Male respondents informed higher scores in technological-based knowledge while females gain higher scores in PK and PCK. These findings were similar to those of other previous studies (e. g. Alkhawaldeh \& Menchaca, 2014).

Qualitatively, the findings support the results of the quantitative findings. Most of the participants talked about barriers in technology integration which seem to influence the score of TK, TPK, TCK, and TPACK. The in-depth information elaborated informed barriers including lack of teacher educators' skill, limited infrastructure, lack of human resource supporting the technology integration, and little support from school principals. Similarly, the barriers informed in this study were also discussed by previous researchers (Chai et al., 2010). In specific term, the barriers include limited technology tools and access of the Internet, teachers' lack of experience, and lack of workshops and seminars were elements to reduce technology integration (Alkhawaldeh \& Menchaca, 2014; Ertmer et al., 2012).

Even though the level of technology-based knowledge was low, the majority of teachers perceived that technology is advantageous to improve instruction. Some advantages that emerged from the session of interviews include technology which facilitates thought-provoking learning situation in the classroom, engages critical learning, and improves peer collaboration among science teachers. The awareness of the technology advantages in instruction was also revealed by previous studies (e.g Dalal et al., 2017; Habibi et al., 2018). They also learn new technology through peer collaboration with their peers (Dalal et al., 2017).

\section{Conclusion}

The findings of this study inform significant and in-depth insight into science teachers' perception of technology integration through the lens of TPACK (technological knowledge, pedagogical knowledge, content knowledge, technological pedagogical knowledge, technological content knowledge, and technological pedagogical and content knowledge). Both the quantitative and qualitative finding revealed the barriers and advantages of technology integration related to TPACK framework. The barriers should be minimized and the advantages should be improved.

The low score of technology-based knowledge should be related to the barriers experience by the participants, science teachers. In order to minimize the barriers, further research involving all stake holders including authorities e.g. school principals, teacher supervisors, and educational department should be conducted. Workshop, seminar, and trainings are suggested to hold in relation to technology integration in instruction. The initial or basic technology skills and pedagogy was important in order to establish selfefficacy of science teacher in technology integration. A platform for the science teachers' TPACK should also be considered to be established. For future science teachers, teacher education programs are recommended to comprehensively hold courses and training to improve the integration of technology into science courses. Further research on science teacher educators and pre-service teachers is also encouraged. Teacher perception on the advantages of technology integration in science classrooms (facilitating thought-provoking learning situation in the classroom, engaging critical learning, and improving peer collaboration among science teachers) should be maintained. Reward and punishment in teaching with technology and its innovation is encouraged to conduct.

\section{Declaration of Conflicting Interests}

The authors declared no potential conflicts of interest with respect to the research, authorship, and/or publication of this article.

\section{Funding}

The authors received no financial support for the research, authorship, and/or publication of this article. 


\section{References}

Adnan, M., \& Tondeur, J. (2018). Preparing the next generation for effective technology integration in education: Teacher educators' perspective. Age, 25(34), 2.

Alkhawaldeh, N.I., \& Menchaca, M. (2014). Barriers to utilizing ICT in education in Jordan. International Journal on E-Learning, 13(2), 127-155.

Awang, H., Aji, Z.M., Yaakob, M.F.M., Osman, W.R.S., Mukminin, A., \& Habibi, A. (2018). Teachers' intention to continue using Virtual Learning Environment (VLE): Malaysian context. Journal of Technology and Science Education, 8(4), 439-452. https://doi.org/10.3926/jotse.463

Barak, M. (2017). Cloud Pedagogy: Utilizing Web-Based Technologies for the Promotion of Social Constructivist Learning in Science Teacher Preparation Courses. Journal of Science Education and Technology, 26(5), 459-469. https://doi.org/10.1007/s10956-017-9691-3

Baran, E., Canbazoglu-Bilici, S., Albayrak-Sari, A., \& Tondeur, J. (2017). Investigating the impact of teacher education strategies on preservice teachers' TPACK. British Journal of Educational Technology.

Barreto, D., \& Orey, M. (2013). Trends and issues in learning, design, and technology. In Educational Media and Technology Yearbook (pp. 3-5). Springer, New York, NY.

Bostancıoğlu, A., \& Handley, Z. (2018). Developing and validating a questionnaire for evaluating the Science 'Total PACKage': Technological Pedagogical Content Knowledge (TPACK) for English as a Foreign Language (EFL). Computer Assisted Language Learning, 1-27.

Chai, C.S., Koh, J.H.L., \& Tsai, C.C. (2010). Facilitating preservice teachers' development of technological, pedagogical, and content knowledge (TPACK). Educational Technology \& Society, 13(4), 63-73.

Chen, Y.H., \& Jang, S.J. (2018). Exploring the Relationship Between Self-Regulation and TPACK of Taiwanese Secondary In-Service Teachers. Journal of Educational Computing Research, 0735633118769442. https://doi.org/10.1177/0735633118769442

Constantine, A., Rozowa, P., Szostkowski, A., Ellis, J., \& Roehrig, G. (2017). The “T” in STEM: How elementary science teachers' beliefs of technology integration translate to practice during a co-developed STEM unit. Journal of Computers in Mathematics and Science Teaching, 36(4), 339-349.

Creswell, J.W. (2014). A concise introduction to mixed methods research. Sage Publications.

Dalal, M., Archambault, L., \& Shelton, C. (2017). Professional Development for International Teachers: Examining TPACK and Technology Integration Decision Making. Journal of Research on Technology in Education, 49(3-4), 117-133. https://doi.org/10.1080/15391523.2017.1314780

Enderson, M.C., \& Watson, G.S. (2019). Preparing Pre-Service STEM Teachers to Teach Using Digital Modeling and Simulation Applications. In Handbook of Research on TPACK in the Digital Age (413-436). IGI Global. https://doi.org/10.4018/978-1-5225-7001-1.ch019

Ertmer, P.A., Ottenbreit-Leftwich, A.T., Sadik, O., Sendurur, E., \& Sendurur, P. (2012). Teacher beliefs and technology integration practices: A critical relationship. Computers \& Education, 59(2), 423-435. https://doi.org/10.1016/j.compedu.2012.02.001

Gne, E., \& Bahivan, E. (2018). A mixed research-based model for pre-service science teachers' digital literacy. Computers \& Education, 118(C), 96-106.

Graham, C., Culatta, R., Pratt, M., \& West, R. (2004). Redesigning the teacher education technology course to emphasize integration. Computers in the Schools, 21(1-2), 127-148.

Graziano, K.J., Herring, M.C., Carpenter, J.P., Smaldino, S., \& Finsness, E.S. (2017). A TPACK diagnostic tool for teacher education leaders. TechTrends, 61(4), 372-379. https://doi.org/10.1007/s11528-017-0171-7 
Habibi, A., Mukinin, A., Riyanto, Y., Prasohjo, L.D., Sulistiyo, U., Sofwan, M. et al.(2018). Building an online community: Student teachers' perceptions on the advantages of using social networking services in a teacher education program. Turkish Online Journal of Distance Education, 19(1), 46-61.

Harris, J.B., \& Hofer, M.J. (2017). “TPACK Stories”: Schools and School Districts Repurposing a Theoretical Construct for Technology-Related Professional Development. Journal of Research on Technology in Education, 49(1-2), 1-15. https://doi.org/10.1080/15391523.2017.1295408

Hsu, C.Y., Tsai, M.J., Chang, Y.H., \& Liang, J.C. (2017). Surveying In-Service Teachers' Beliefs about Game-Based Learning and Perceptions of Technological Pedagogical and Content Knowledge of Games. Educational Technology \& Society, 20(1), 134-143.

Ifinedo, E., Kankaanranta, M., Neittaanmäki, P., \& Hämäläinen, T. (2017). Exploring Nigerian University Students' Perception towards Mobile Learning. In EdMedia: World Conference on Educational Media and Technology (833-842). Association for the Advancement of Computing in Education (AACE).

Incikabi, L. (2019). Teaching history of mathematics through digital stories: A technology integration model. In Early Childhood Development: Concepts, Methodologies, Tools, and Applications (705-720). IGI Global. https://doi.org/10.4018/978-1-5225-7507-8.ch034

ISTE (2018). Standard for educators. International Society for Technology in Education.

Jang, S.J., \& Tsai, M.F. (2013). Exploring the TPACK of Taiwanese secondary school science teachers using a new contextualized TPACK model. Australasian Journal of Educational Technology, 29(4). https://doi.org/10.14742/ajet.282

Joo, Y.J., Park, S., \& Lim, E. (2018). Factors Influencing Preservice Teachers' Intention to Use Technology: TPACK, Teacher Self-efficacy, and Technology Acceptance Model. Journal of Educational Technology \& Society, 21(3).

Kale, U. (2018). Technology valued? Observation and review activities to enhance future teachers' utility value toward technology integration. Computers \& Education, 117, 160-174.

https://doi.org/10.1016/j.compedu.2017.10.007

Koh, J.H.L., Chai, C.S., \& Lim, W.Y. (2017). Teacher professional development for TPACK-21CL: Effects on teacher ICT integration and student outcomes. Journal of Educational Computing Research, 55(2), 172196. https://doi.org/10.1177/0735633116656848

Krause, J.M. (2017). Physical Education Student Teachers' Technology Integration Self-Efficacy. Physical Educator, 74(3), 476. https://doi.org/10.18666/TPE-2017-V74-I3-7329

Lawrence, J.E., \& Tar, U.A. (2018). Factors that influence teachers' adoption and integration of ICT in teaching/learning process. Educational Media International, 55(1), 79-105.

https://doi.org/10.1080/09523987.2018.1439712

Lee, M.H., \& Tsai, C.C. (2010). Exploring teachers' perceived self efficacy and technological pedagogical content knowledge with respect to educational use of the World Wide Web. Instructional Science, 38(1), $1-21$.

Lin, T.C., Tsai, C.C., Chai, C.S., \& Lee, M.H. (2013). Identifying science teachers' perceptions of technological pedagogical and content knowledge (TPACK). Journal of Science Education and Technology, 22(3), 325-336. https://doi.org/10.1007/s10956-012-9396-6

Martin, B. (2018). Faculty technology beliefs and practices in teacher preparation through a TPaCK lens. Education and Information Technologies, 23(5), 1775-1788. https://doi.org/10.1007/s10639-017-9680-4

Miles, M.B., \& Huberman, A.M. (1994). Qualitative data analysis: An expanded sourcebook. Sage Publications.

Mishra, P., \& Koehler, M.J. (2006). Technological pedagogical content knowledge: A framework for teacher knowledge. Teachers college record, 108(6), 1017. https://doi.org/10.1111/j.1467-9620.2006.00684.x 
Niederhauser, D.S., \& Lindstrom, D.L. (2018). Instructional Technology Integration Models and Frameworks: Diffusion, Competencies, Attitudes, and Dispositions. Handbook of Information Technology in Primary and Secondary Education, 1-21.

Niess, M.L. (2018). Scaffolding Subject Matter content with pedagogy and technologies in problem-based learning with the online TPACK learning trajectory. In Teacher Training and Professional Development: Concepts, Methodologies, Tools, and Applications (914-931). IGI Global. https://doi.org/10.4018/978-1-5225-5631-2.ch040

Scherer, R., Tondeur, J., Siddiq, F., \& Baran, E. (2018). The importance of attitudes toward technology for pre-service teachers' technological, pedagogical, and content knowledge: Comparing structural equation modeling approaches. Computers in Human Behavior, 80, 67-80. https://doi.org/10.1016/j.chb.2017.11.003

Shulman, L. (1987). Knowledge and teaching: Foundations of the new reform. Harvard educational review, $57(1), 1-23$.

Stake, R.E. (1995). The art of case study research. Thousand Oaks, CA: Sage.

Suana, W. (2018). Students' Internet Access, Internet Self-Efficacy, and Internet for Learning Physics: Gender and Grade Differences. Journal of Technology and Science Education, 8(4), 281-290.

https://doi.org/10.3926/jotse.399

Tchoshanov, M., Cruz, M.D., Huereca, K., Shakirova, K., Shakirova, L., \& Ibragimova, E.N. (2017). Examination of lower secondary mathematics teachers' content knowledge and its connection to students' performance. International Journal of Science and Mathematics Education, 15(4), 683-702. https://doi.org/10.1007/s10763-015-9703-9

Thibaut, L., Knipprath, H., Dehaene, W., \& Depaepe, F. (2018). The influence of teachers' attitudes and school context on instructional practices in integrated STEM education. Teaching and Teacher Education, 71, 190-205. https://doi.org/10.1016/j.tate.2017.12.014

Tondeur, J., Scherer, R., Siddiq, F., \& Baran, E. (2017). A comprehensive investigation of TPACK within pre-service teachers' ICT profiles: Mind the gap. Australasian Journal of Educational Technology, 33(3), 46-60. https://doi.org/10.14742/ajet.3504

Yerdelen-Damar, S., Boz, Y., \& Aydın-Günbatar, S. (2017). Mediated effects of technology competencies and experiences on relations among attitudes towards technology use, technology ownership, and selfefficacy about technological pedagogical content knowledge. Journal of Science Education and Technology, 26(4), 394-405. https://doi.org/10.1007/s10956-017-9687-z

Yurdakul, I.K. (2018). Modeling the relationship between pre-service teachers' TPACK and digital nativity. Educational Technology Research and Development, 66(2), 267-281. https://doi.org/10.1007/s11423-017-9546-x

Published by OmniaScience (www.omniascience.com)

Journal of Technology and Science Education, 2019 (www.jotse.org)

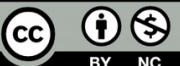

Article's contents are provided on an Attribution-Non Commercial 4.0 Creative commons International License. Readers are allowed to copy, distribute and communicate article's contents, provided the author's and JOTSE journal's names are included. It must not be used for commercial purposes. To see the complete licence contents, please visit https://creativecommons.org/licenses/by-nc/4.0/. 